\title{
The Urban Conservation Approach of Cittaslow Yalvaç
}

\author{
Cittaslow Yalvaç'ın Kentsel Koruma Yaklaşımı
}

\author{
Ayça ÖZMEN, ${ }^{1}$ Mehmet Cengiz CAN ${ }^{2}$
}

\section{ABSTRACT}

Cittaslow International, which is a network of small cities and towns that embrace the Slow Movement in the field of city management, was founded in 1999 in Italy. As of May 2017, there were 235 Cittaslow cities in 30 countries, and 14 are located in Turkey. The first Turkish Cittaslow community was Seferihisar, which is also the headquarters of the Cittaslow National Network of Turkey. Yalvaç, a town and district in the province of Isparta, in the Mediterranean region of Turkey, was accepted as a member of Cittaslow International in 2012. A Project for the protection and development of cultural and environmental values and tourism diversification initiated by the Yalvaç municipality; one of the leading heritage non-governmental organizations (NGOs) in Turkey, the Foundation for the Protection and Promotion of the Environment and Cultural Heritage; universities; other NGOs; and the Ministry of Culture and Tourism in the early 2000s, played an important role in obtaining this Cittaslow membership. This study examines the Yalvaç case and explores how a historic Turkish town developed an approach to urban conservation years ago, before seeking Cittaslow membership, and how this approach affected its membership in the association and the concept of slowness. It also discusses the interaction between its implementations in the field of urban conservation and its Cittaslow membership in terms of slowness.

Keywords: Cittaslow Movement; Isparta; Slow Movement; tempo giusto; urban conservation; Yalvaç.

ÖZ

Yavaşlık Hareketi'ni kent yönetimi alanında benimseyen küçük kentler ağı olan Cittaslow Birliği, 1999 yılında İtalya'da kurulmuştur. 2017 yılı Mayıs ayı itibariyle, dünyada 30 ülkede 235 Cittaslow yerleşimi bulunmaktadır. Bu kentlerden 14'üülkemiz sınırları içinde yer almaktadır. Türkiye'nin ilk Cittaslow yerleşimi, bugün Cittaslow Ulusal Ağı́nın da merkezi olan Seferihisar'dır. Akdeniz Bölgesi'nde yer alan ve Isparta'nın bir ilçesi olan Yalvaç ise, 2012 yılında Uluslararası Cittaslow Birliği'ne üye olmuştur. Cittaslow statüsünün elde edilmesinde, 2000'li yılların başında Yalvaç Belediyesi, ÇEKÜL, üniversiteler, sivil toplum örgütleri ve Kültür ve Turizm Bakanlığı işbirliğinde başlatılan "Yalvaç Kültürel - Doğal Değerlerin Korunması, Geliştirilmesi ve Turizmin Çeşitlendirilmesi Projesi" önemli rol oynamış; Cittaslow üyeliğinin altyapısını oluşturmuştur. Bu makalede, Yalvaçörneği üzerinden, Cittaslow Birliği'ne üye bir tarihi yerleşimin, bu üyelikten yıllar önce bağımsız olarak geliştirdiği koruma yaklaşımına ve bu yaklaşımın süreç içinde bu birliğe katılmasını nasıl etkilediğine değinilmiş; kentin kentsel koruma alanında yaptığı uygulamalar ile Cittaslow üyeliğinin birbirine olan etkileşimi yavaşlık düşüncesi üzerinden tartışılmıştır.

Anahtar sözcükler: Cittaslow Hareketi; Isparta; Yavaşlık Hareketi; tempo giusto; kentsel koruma; Yalvaç.

'Department of Conservation and Restoration of Cultural Property, Yıldız Technical University Faculty of Architecture, İstanbul, Turkey 2Department of Restoration, Yıldız Technical University Faculty of Architecture, İstanbul, Turkey

Article arrival date: June 12, 2017 - Accepted for publication: December 12, 2017

Correspondence: Ayça ÖZMEN. e-mail: aycaozmen@gmail.com

○ 2018 Yıldız Teknik Üniversitesi Mimarlık Fakültesi - ๑ 2018 Yıldız Technical University, Faculty of Architecture 


\section{Introduction}

Today's globalizing world has been presenting us rapid lifestyles, increscent endeavors and redundant consumption habits. ${ }^{1}$ In this context, time equals to money and should be utilized fast and efficiently. However, aforecited accelerating pace of life and consumption habits bring exhaustion and unhappiness on society ${ }^{2}$ and damages environment and natural resources, as well. As a response to this trend, Slow Movement which lays emphasis on living in meaningful, sustainable, attentive and convivial way, has ensued. ${ }^{3}$ Slowness does not mean to decelerate contemporary pace of life but means to utilize it more carefully and consciously. ${ }^{4}$ In this sense, term "slow" is used as signifying tranquil, quiet, intuitional, patient, careful, calm, cogitative and qualitative, in contrast to term "fast" inferred as busy, impatient, aggressive, stressful, superficial, hasty, active and quantitative. ${ }^{5}$

"Slow" is directly related with time, however it does not mean to do everything in pace of a snail. Moreover, it is not a conservative movement which rejects technology and takes a stand against modernity. ${ }^{6}$ The main goal of this movement is creating more time consciously and appreciating and enjoying what we are engaged in daily life. ${ }^{7}$ The most important point is seeking "tempo giusto" which means the right pace for a person, case or thing, ${ }^{8}$ being in accordance with their own inner tempo. Nowadays, Slow approach is embraced globally in many fields such as gastronomy, city management, tourism, etc. Among them, Cittaslow which deals with small town management will be mentioned onwards.

On the other hand, in historic environments, cultural and natural heritage has been cumulatively formed in its own inner pace; or to put it differently, in tempo giusto of its settings through long ages. Recently, these formations are disappearing fast and seriously in consequence of hasty, rent based unplanned and inattentive interventions. As a result, despite many historical settings are seen physically well-cared and healthy, they have already lost their genius loci and identity and turned into paper movie sets. Though, settlements have been formed cumulatively by time and transformed by their own dynamics. Therefore, protecting cultural and natural heritage in historical settlements in their own dynamics and transmitting it to the next generation should be an important responsibility for everyone. In this context, the way of protecting historic environments should involve Slow approach which exists in the essence of both historical assets and conservation action as mentioned above. ${ }^{9}$

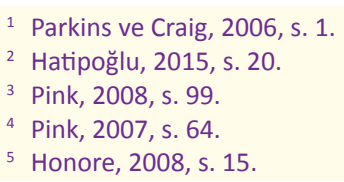

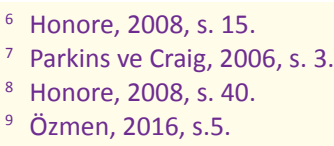

In order to reveal this premise, Yalvaç (Isparta), both a small historic town and a member of Cittaslow Association since 2012, is selected as a case study. It is not only a Cittaslow and a historical town at the same time, but also has been implementing an integrated conservation project for more than 15 years. In this sense, with the case of Yalvaç (Isparta), the relationship between urban conservation approach and slow movement practices in the field of city management will be studied in this paper. For that purpose, how a Turkish Cittaslow historic settlement had developed its urban conservation approach years ago apart from Cittaslow membership and how this approach had affected its attendance to the Association will be analyzed. Moreover, the interaction between its urban conservation practices and Cittaslow implementations in terms of "Slow" will be discussed.

To add more, methodologically, after the elaborated literature research about urban conservation and Cittaslow in particular, on site observation and interviews with locals and authorities were realized to form this paper.

\section{International Cittaslow Association}

International Cittaslow Association, founded in 1999 in Orvieto-Italy led by the mayors of four Italian towns such as Greve in Chianti, Bra, Orvieto, Positano and the founder of Slow Food Association, introduces a multi-dimensional local administration programme by embracing Slow approach. Its main goal is increasing the inhabitants' quality of life by protecting and sustaining the local values of small settlements with the population of less than 50.000 . Its philosophy is based on a Latin phrase "festina lente" which can be translated as "being slowly hasty" implies looking for each day the contemporary equivalent, or to put it differently, searching the best knowledge of yesterday and appraising it by means of the possibilities of today and tomorrow. ${ }^{10}$ Cittaslow vision also aims to maintain the town's distinctive features while developing the town in such a way that the inhabitants enjoy life in better environments. ${ }^{11}$

International Cittaslow Association has a charter consisting of 29 principal and 5 additional articles. In the charter, it is mentioned that the name "Cittaslow" shall not be translated into any other language. Moreover, this charter presents headquarters, history, principles, values, symbol, official languages, funds, international and national organization structure, participation conditions, responsibilities, rights and membership requirements of the Association. One of the most significant parameters of the charter is Cittaslow criteria, or in other words "requirements for excellence" as mentioned by charter. Cittaslow criteria are

\footnotetext{
${ }^{10}$ Cittaslow International Web Sayfası, Philosophy; Miele, 2008, s. 139.

${ }^{11}$ Radstrom, 2011, s. 96.
} 


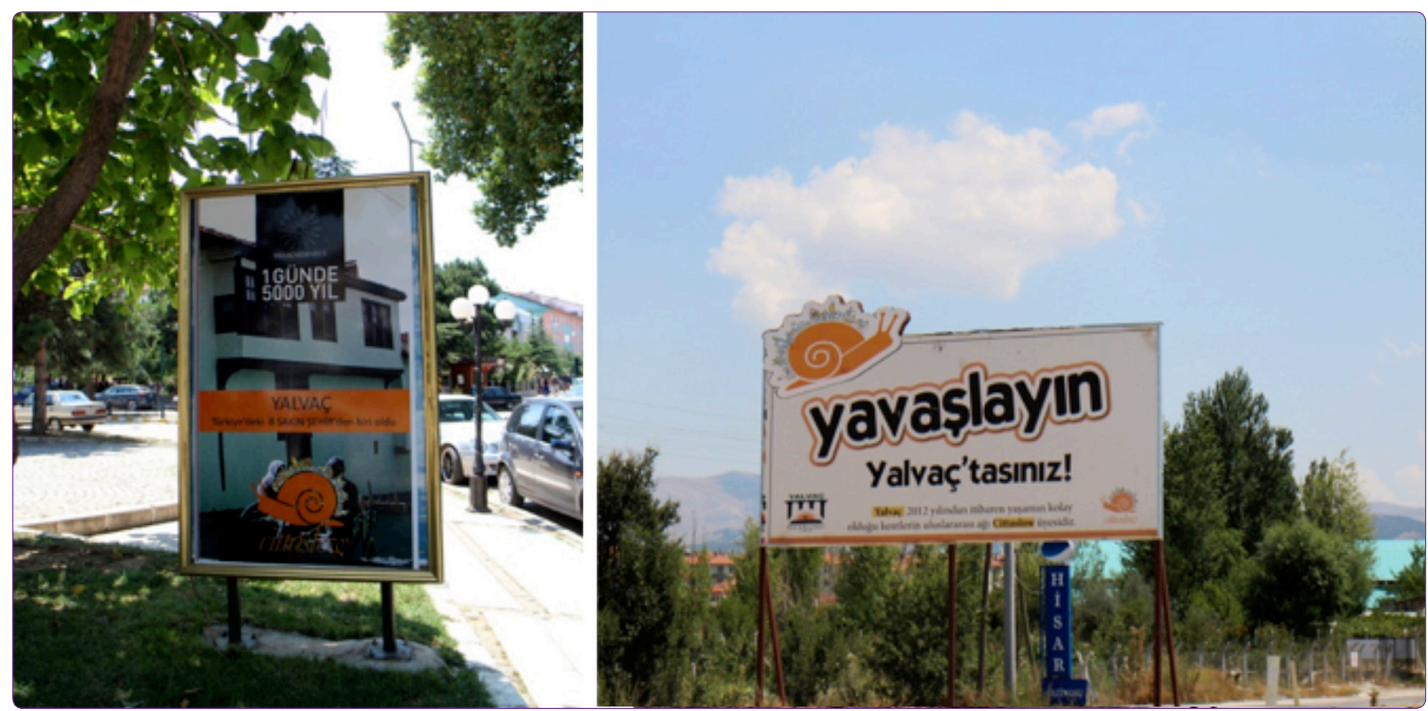

Figure 1. Slogan and Cittaslow Logo of Yalvaç.

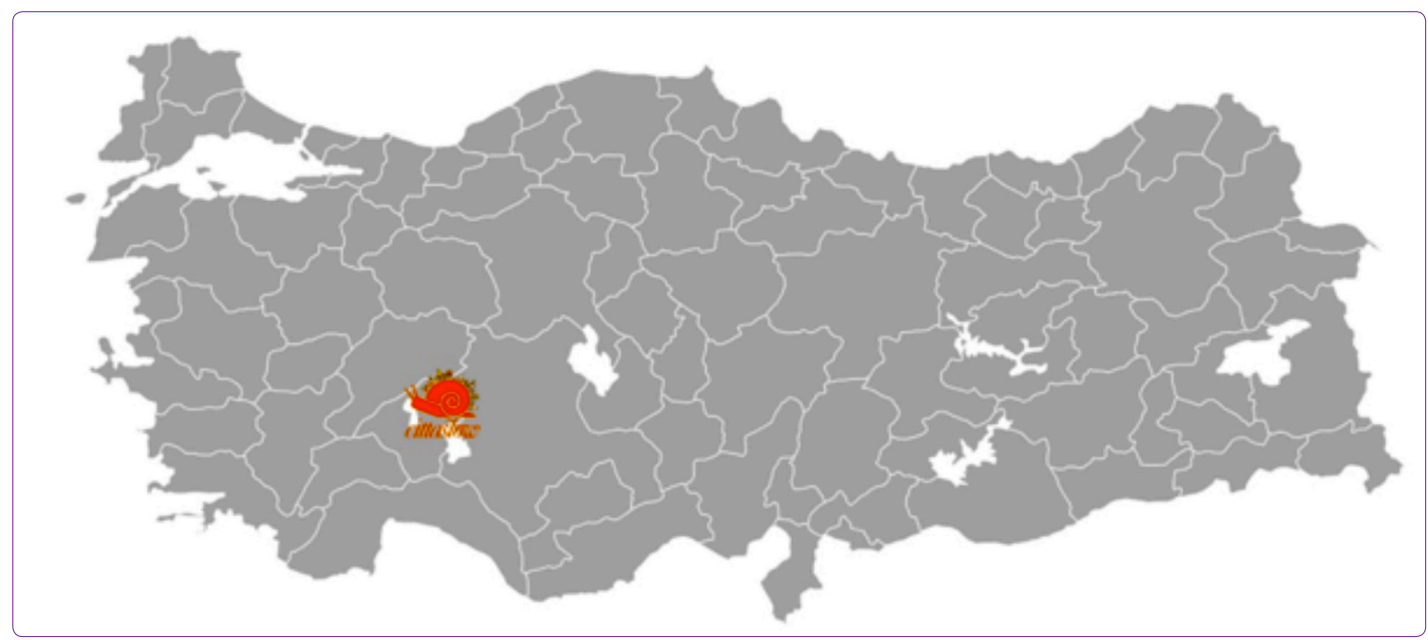

Figure 2. Location of Yalvaç on Map of Turkey.

made up of 71 requirements, grouped under seven main topics such as energy and environmental policies, infrastructure policies, quality of urban life policies, agricultural, touristic and artisan policies, policies for hospitality, awareness and training, social cohesion and partnerships. It is necessary for towns to carry out at least $50 \%$ of these requirements for enrolling the association. ${ }^{12}$

According to Second Global Report on the Cittaslow Towns of 2015, 73\% of Cittaslow settlements in the world have historical centers with outstanding architectural value. $61 \%$ of them have cultural, architectural, historical and artistic heritage and $49 \%$ of them still maintain their traditional handicrafts. These facts show that most of the Cittaslow settlements are historical towns with existing cultural heritage. ${ }^{13}$

\footnotetext{
12 International Cittaslow Charter, 2014.

${ }^{13}$ Second Global Report on the Cittaslow Towns, 2015.
}

Since May 2017, there are 235 Cittaslow settlements among 30 countries. 89 of them are situated in the constituent country, Italy and 14 of them are in Turkey. These Turkish towns are Akyaka (Muğla), Eğirdir (Isparta), Gerze (Sinop), Gökçeada (Çanakkale), Göynük (Bolu), Halfeti (Şanlıurfa), Perşembe (Ordu), Seferihisar (izmir), Şavşat (Artvin), Taraklı (Sakarya), Uzundere (Erzurum), Vize (Kırklareli), Yalvaç (Isparta), Yenipazar (Aydın).

In 2009, the first Turkish Cittaslow settlement, Seferihisar was attended to the Cittaslow Association and became the headquarter of Cittaslow National Network of Turkey few years later. Besides, Yalvaç, researched for this paper, was participated to Cittaslow Association in 2012 (Figure 1).

\section{Yalvaç}

Yalvaç is located in Mediterranean region of Turkey as a town of Isparta (Figure 2). It is surrounded by towns of Se- 
nirkent, Gelendost and Şarkikaraağaç, cities of Afyon and Konya and Lake of Eğirdir. The distance between Isparta and Yalvaç is $110 \mathrm{~km}$. Yalvaç's surface area is $1415 \mathrm{~km}^{2}$ and its population is 47.769 according to Turkish Statistical Institute data from 2015. It has 37 villages and 27 neighborhoods. ${ }^{14}$

The history of town dates back to Late Neolithic period. ${ }^{15}$ Due to archeological surveys, known first settlements were taken hold in 3000 A.D. and therefore, its slogan is "Yalvaç Civilization, 5000 years in one day". During 2000 A.D., it was occupied by Kingdom of Arzawa. ${ }^{16}$ In $4^{\text {th }}$ century A.D. this region was involved to Kingdom of Macedonia, in $3^{\text {rd }}$ century A.D to Seleukos, in $2^{\text {nd }}$ century A.D to Kingdom of Pergamon and in 130 A.D. to Roman Empire. During Augustus Period, in $1^{\text {st }}$ century, Antioch of Pisidia was founded as one of the Roman colonies. After the division of Roman Empire in 395, the area was ruled by Byzantines. ${ }^{17}$ In 1176, during Kılıçaraslan the second, this area came under the occupation of Anatolian Seljuks. However, they settled into the plain area outside the ancient Antioch. In $14^{\text {th }}$ century during period of Beyliks, the domination was taken by Hamitoğulları and Karamanoğulları, respectively. In 1415, it became an Ottoman town under Konya. In 1864, municipality was organized for the first time and since founding of the Republic of Turkey, it has been a municipal town of Isparta. ${ }^{18}$

The major source of income of Yalvaç is agriculture. The $35 \%$ of inhabitants are living in city center and the rest in villages; and four fifth are engaged in agriculture. Moreover, cattle and sheep farming and traditional handicrafts such as tanning, carpet making, mining, coppersmithing, forging, and spring cart manufacture contribute to town's economy. Even if just a smidgen, other traditional handicrafts such as weaving, saddle making, tinsmithing, blacksmithing, etc are being sustained. The tradition of Ahi community still exists through craftsmen establishments such as Tabaklar, Abacılar, Leblebiciler, Yağcılar and Terziler. ${ }^{19}$ Recently, it is remarkable that industrialization has also been developed. As a result, many people are immigrating from nearby settlements to get jobs. ${ }^{20}$

\section{Historical, Cultural and Natural Assets of Yalvaç}

In Yalvaç, there are two different built-up areas. One is the hill where the ancient Antioch of Pisidia was founded and the other is the plain where Anatolian Seljuks settled. ${ }^{21}$

Today, Ancient Antioch of Pisidia is a significant archeological site with the remains of St. Paul's Church, Augustus Temple, Tiberius Square, Theater, Aqueducts, Roman Bath

\footnotetext{
14 Yalvaç Kaymakamlığı Web Sayfası, Yönetim.

Müdürlüğü, 2010, s. 227-228.

${ }^{18}$ Akkan, 2006, s. 10-11.

${ }^{15}$ Isparta Valiliği il Kültür ve Turizm ${ }^{19}$ Akkan, 2006, s. 22.

Müdürlüğü, 2010, s. 227.

${ }^{16}$ Akkan, 2006, s. 7-8.

${ }^{17}$ Isparta Valiliği il Kültür ve Turizm
}

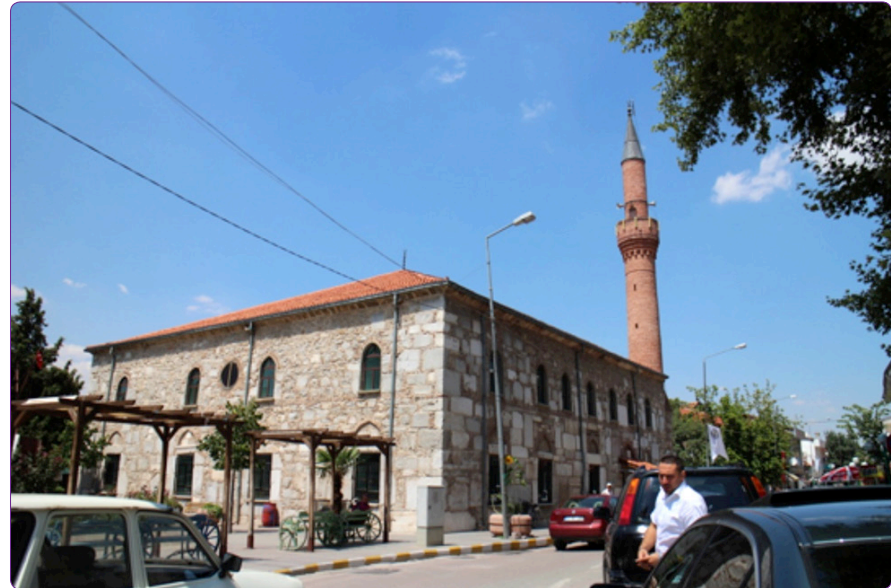

Figure 3. Devlethan Mosque from Beyliks Period.

and city portal. ${ }^{22}$ On the other side, the plain, called Yalvaç today, is being settled continuously for almost 850 years with features of typical Turkish town. Old town core hosts Devlethan Mosque from the period of Beyliks (Figure 3), traditional trade and market places and recent administrative and cultural buildings around this Mosque, 800 years old monumental tree which is the symbol of town. Around this historic core, traditional neighborhoods are located. These neighborhoods are still protecting and maintaining the traces of traditional town life with their old wooden houses, organic street patterns and their core facilities such as mosques, Turkish baths and furnaces. Besides, they have been called with the same names at least for 500 years which was understood from $16^{\text {th }}$ century records. ${ }^{23}$

The organic street pattern of Yalvaç was formed by traditional civil architecture and rubble or mud walls of their porches (Figure 4). Vernacular architecture has mostly two-storey. It was built with timber frame structure filled with mud bricks or adobe masonry. On the other side, from foundations to subbasement floor, stone masonry technique was used. Among the rubble stones of their subbasement floors, spolia from ancient Antioch may be found occasionally (Figure 5). The facades, mostly covered by earthen plaster, are simple and unadorned. Some of them have cantilevers or projections with wooden corbels. Most of the earth sheltered houses were transformed into gable roof in time. Traditional houses with external halls have some traditional interior architectural elements such as cabinets, shelves, dish racks, stoves, ceilings, inner doors and windows. ${ }^{24}$

According to Isparta Cultural Inventory of year 2010, in Yalvaç, there are 46 examples of registered vernacular architecture from $19^{\text {th }}$ century, 15 mosques from Beyliks and Ottoman Period, a fountain from Beyliks Period, a bath from Ottoman Period, a bridge from Anatolian Seljuks Pe-

\footnotetext{
22 Isparta İ Kültür ve Turizm Müdürlüğü Web ${ }^{23}$ Akkan, 2006, s. 18-19. Sayfası, Aziz Paulus; Akkan, Ş., 2006, s.16-17. $\quad{ }^{24}$ Akkan, 2006, s. 24-62.
} 

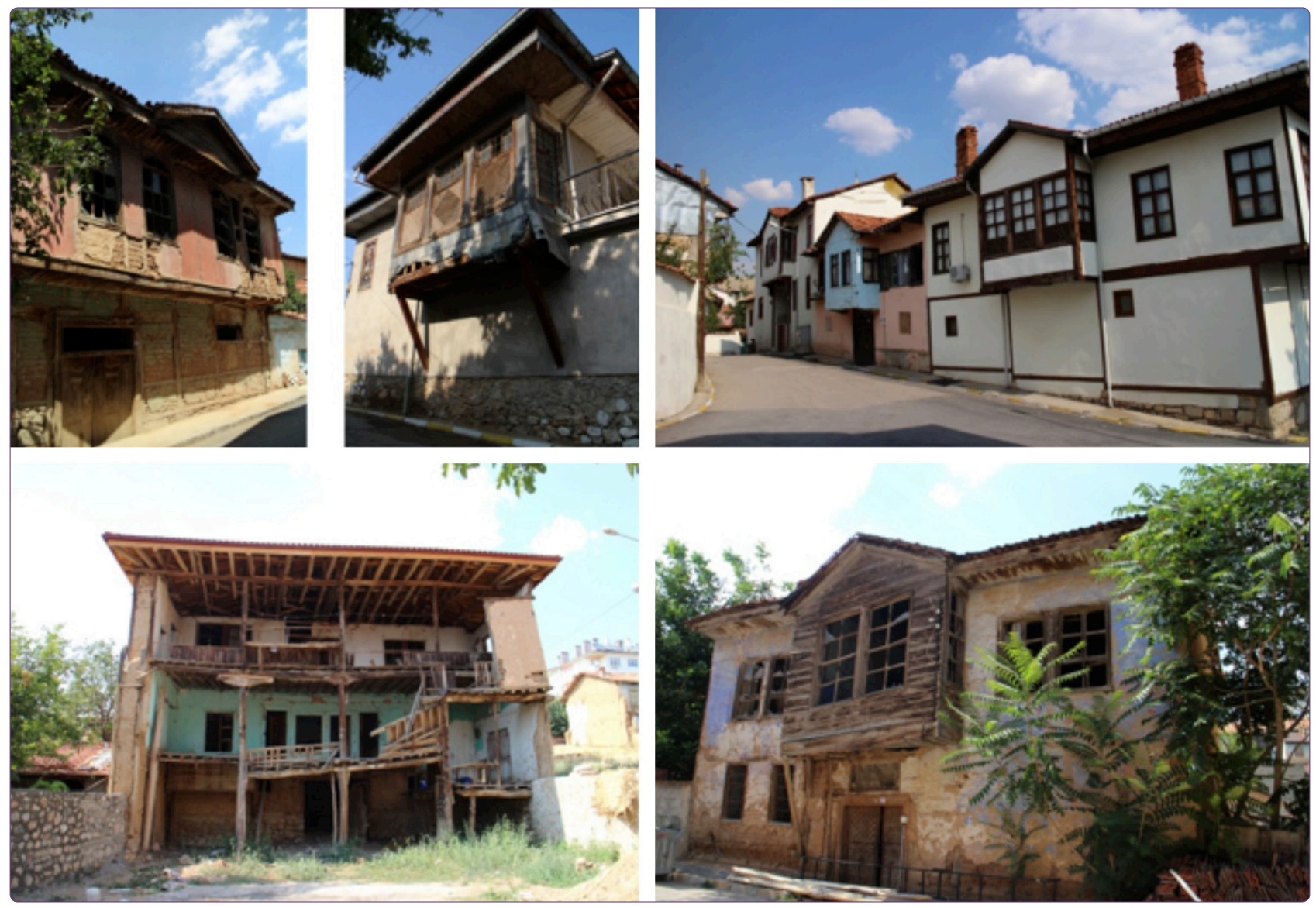

Figure 4. Some Examples From Yalvaç's Vernacular Architecture.

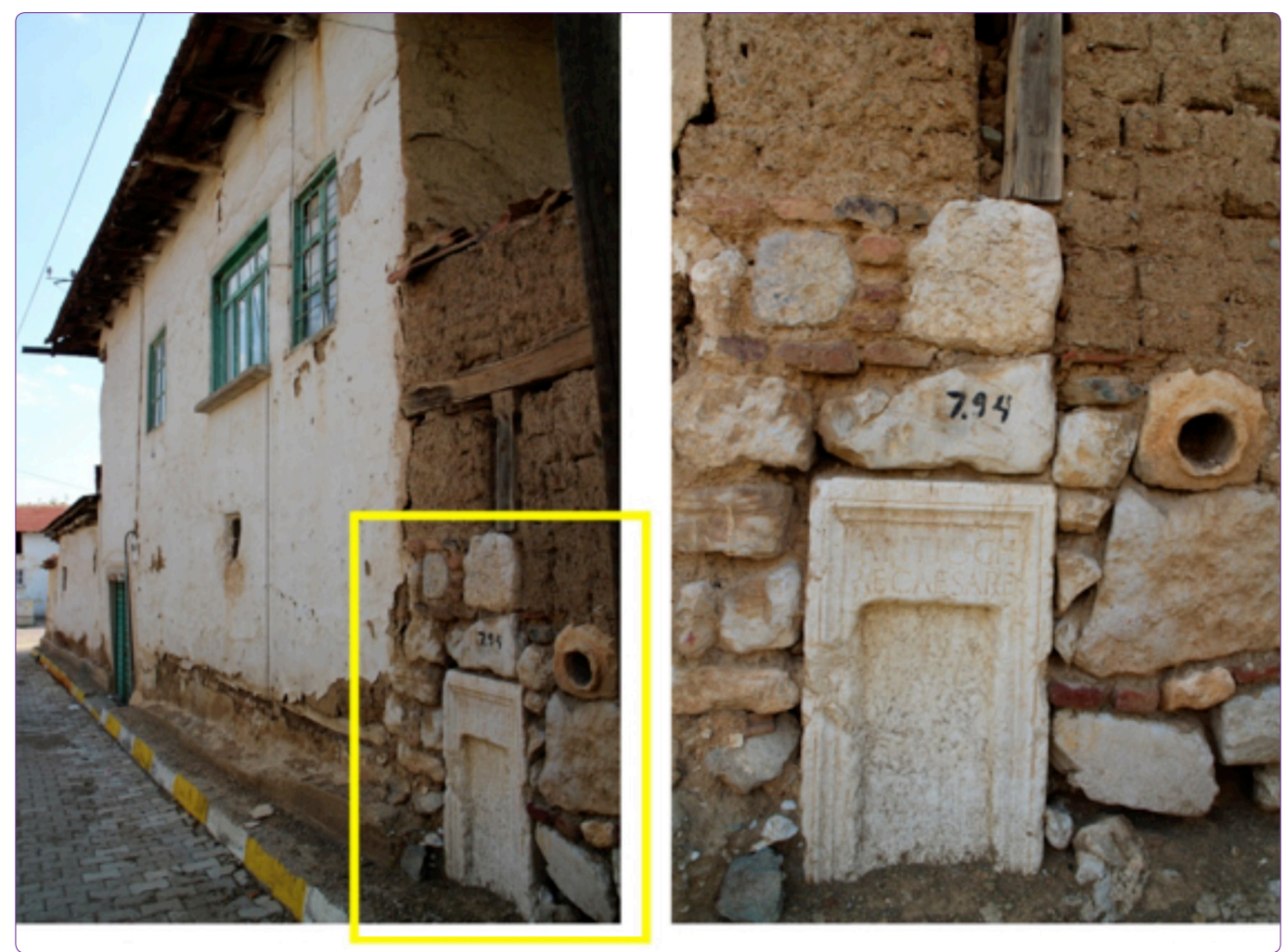

Figure 5. Use of Spolia from Ancient Antioch. 


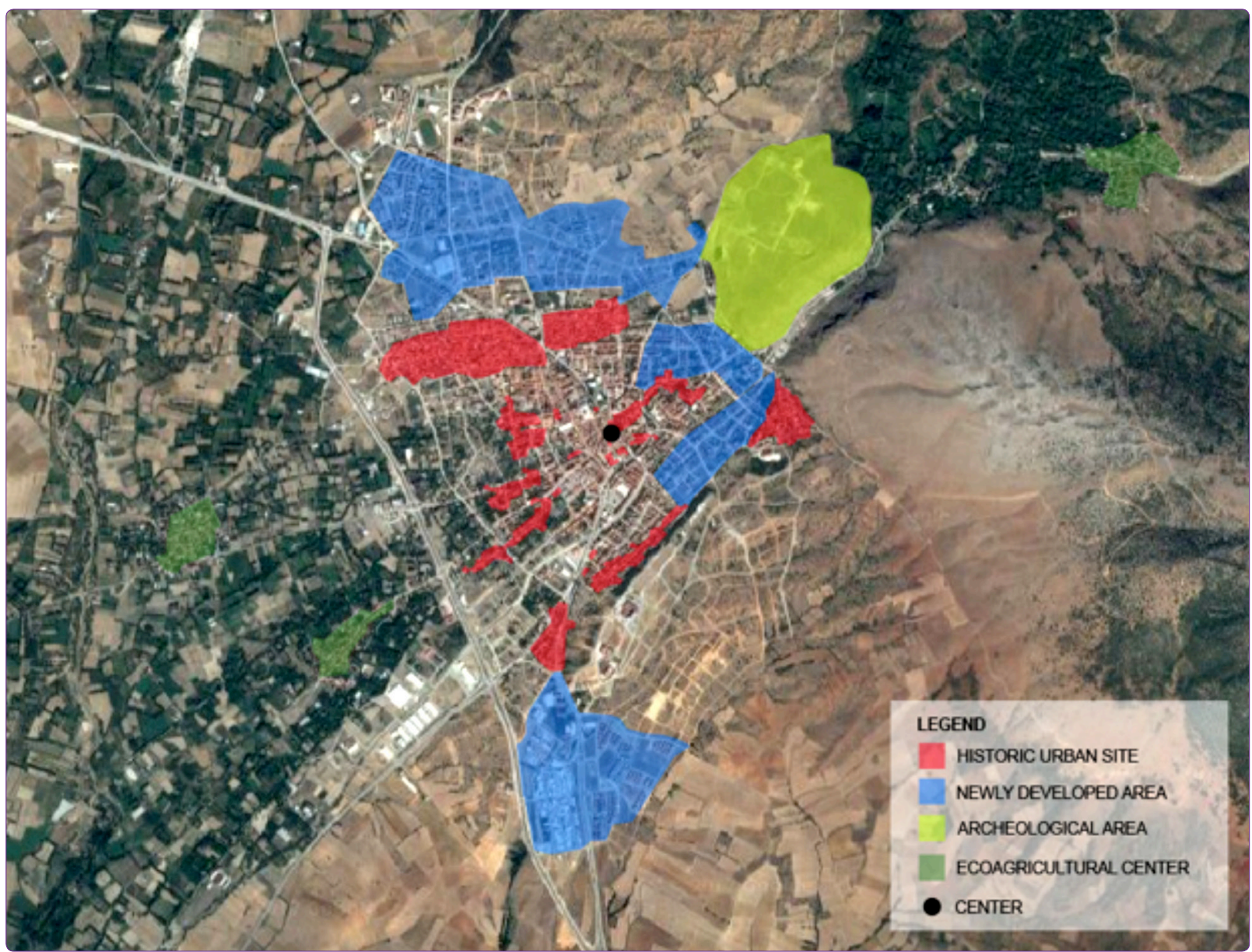

Figure 6. Map of Yalvaç (derived from Google Maps).

riod, four industrial buildings dating back to $19^{\text {th }}$ century, 3 monumental trees, 17 tumulus, an ancient city (Antioch of Pisidia) and 6 ancient ruins. ${ }^{25}$

A traditional Turkish town, Yalvaç does not have either an urban protected area or a conservation oriented zoning which are declared by Regional Council for the Conservation of Cultural Property, yet. Moreover, according to Akkan, 1985's town master plan, which is still in use, does not involve any proposals about conservation approaches for traditional buildings and sites. ${ }^{26}$ However, work has been initiated to make a new master plan which will incorporate in decisions and proposals for conservation measures. ${ }^{27}$

Since 1970, the rate of construction has accelerated and the vineyards and green areas between traditional neighborhoods have filled with multi-storey reinforced concrete buildings. ${ }^{28}$ The increscent population, as a result of both establishing new industrial fields and vocational school, had led to new housing demands. Therefore, the town tends to grow along north-south direction (Figure 6). ${ }^{29}$

\footnotetext{
${ }^{25}$ Isparta Valiliği il Kültür ve Turizm ${ }^{27}$ Yalvaç Belediyesi, 2011. Müdürlüğü, 2010.

${ }^{28}$ Akkan, 2006, s. 22.

${ }^{26}$ Akkan, 2006, s. 3.

${ }^{29}$ Akkan, 2006, s. 23.
}

The Participation of Yalvaç to International Cittaslow Association

Yalvaç, one of the founding cities of Turkish Union of Historical Towns (Tarihi Kentler Birliği), has been a member of Cittaslow Association since 2012. "Project of Yalvaç Protection and Development of Cultural and Environmental Values and Tourism Product Diversification", initiated with the cooperation of Yalvaç Municipality, Turkish Union of Historical Towns (Tarihi Kentler Birliği), The Foundation for the Protection and Promotion of the Environment and Cultural Heritage (ÇEKÜL), universities, non-governmental organizations and Ministry of Culture in the beginning of 2000's, has played important role to prepare a substructure for Cittaslow membership and obtain Cittaslow status afterwards. Today, in Yalvaç, this aforementioned project and Cittaslow requirements continue to work in liaison with each other. ${ }^{30}$

Major outputs of Yalvaç for Cittaslow requirements for excellence: ${ }^{31}$

- Energy and environmental policies: providing energy

\footnotetext{
${ }^{30}$ Yalvaç Belediyesi, $2011 . \quad{ }^{31}$ Yalvaç Belediyesi, 2011.
} 
efficiency by promoting solar energy use and raising public awareness, preparing energy performance certificate for buildings, ${ }^{32}$ making plan for solid waste management, operating existing wastewater treatment plant, decreasing noise pollution by moving industrial areas outside the town, constructing bypass for transit cars, regulating the level of noise in the center, etc., decreasing light pollution by placing smart lighting systems into the public zones, implementing related national and municipal laws and regulations ${ }^{33}$ for environmental policies.

- Infrastructure policies: arranging bike and new pedestrian routes, promoting use of bicycle town-wide, reusing spring cart in urban transportation, regulating car park areas near town entrances, improving public transportation system by supplementing new public bus routes, renewing traffic signs and placing additional ones for facilitating transportation, rearranging roads and sidewalks for everybody's access.

- Quality of urban life policies: sustaining archeological surveys in Antioch, identifying and registering historical buildings and sites, implementing urban sanitization in historic neighborhoods, restoring Tıraşzade Mansion and reutilizing it as an ethnography museum, restoring old leather factory and reutilizing it as a guest house and open air museum, setting up a town museum, establishing neighborhood art galleries, generating cultural routes starting from center to historic neighborhoods and archeological sites, identifying and maintaining intangible cultural heritage, arranging in every neighborhood at least a park with all facilities such as walking trails, playgrounds, sport fields, etc., using communication technologies for municipal purpose, planting, seedling and designing green areas with local plants such as rose, registering monumental trees, rehabilitating traditional craft bazaars called blacksmith and shoemaking and establishing new craft centers for sustaining traditional crafts, generating market places for women employment, organizing producer, peasant and milk-based product markets.

- Agricultural, touristic and artisan policies: declaring Hisarardı Village, Salur and Sofular Neighborhoods as eco-agriculture region, rehabilitating old wooden houses in Hisarardı Village for eco-tourism purpose, restoring historical buildings to reutilize them as guest houses, introducing, revitalizing and maintaining traditional crafts such as felt, blacksmith, saddler, leather, etc., training apprentices in these traditional crafts, recording and keeping

\footnotetext{
32 In accordance with Energy Efficiency Law no. 26510.

${ }^{33}$ In accordance with Environmental Law no. 2872, regulations on solid waste control, packaging waste control, ambient noise assessment and management, waste and stor-
}

their production processes digitally, encouraging organic agriculture $^{34}$ in fruits (apple, cherry, apricot) and vegetable growing, preserving and featuring local products such as buffalo cream, keşkek, hamursuz, güllaç, traditional bread, etc. and promoting their marketing country-wide, establishing Yalvaç Food Culture House cooking with these local products and traditional recipes, organizing local cultural events such as Hidırellez Festival and Pisidia Antioch Culture, Tourism and Art Fest.

- Policies for hospitality, awareness and training: publicizing town's tourism in national extent via publications, social and printed media, publishing bilingual booklets for touristic purpose, raising awareness of tourism operators and traders via seminars in cooperation with Provincial Directorate of Culture and Tourism, raising public awareness via media, training locals in the fields of agriculture and farming, giving vocational courses in liaison with Public Training Center.

- Social cohesion: supplying employment for women by generating market place and for youth by training them in the field of traditional crafts.

- Partnerships: being in collaboration with Turkish Union of Historical Towns, the Foundation for the Protection and Promotion of the Environment and Cultural Heritage, universities, non-governmental organizations and Ministry of Culture for the project of Yalvaç Protection and Development of Cultural and Environmental Values and Tourism Product Diversification.

The Project of Yalvaç Protection and Development of Cultural and Environmental Values and Tourism Product Diversification

Project of Yalvaç Protection and Development of Cultural and Environmental Values and Tourism Product Diversification, which received Metin Sözen Conservation Grand Prix in 2003 and Derviş Parlak 10th year Special Award in 2010 from Turkish Union of Historical Towns, had facilitated the participation of town in Cittaslow Association as it is mentioned above. On account of being corresponded to each other, the outputs of this project are standing for most of the Cittaslow requirements ${ }^{35}$ which should be provided for obtaining Cittaslow status (Table 1).

Yalvaç Municipality is the owner and Chamber of Architects of Antalya and the Foundation for the Protection and Promotion of the Environment and Cultural Heritage (ÇEKÜL) are the partners of this project. Moreover, Ministry of Culture and Tourism, Governorship of Isparta, West Mediterranean Development Agency (BAKA) and several universities are contributors. Within the scope of this project, the survey of vernacular architecture was carried out by the stu-

\footnotetext{
${ }^{35}$ Particularly the ones in infrastructure policies, quality of urban life policies, agricultural, touristic and artisan policies, policies for hospitality, awareness and training, social cohesion and partnerships.
} 
Table 1. Classification of Project Outputs of Yalvaç Protection and Development of Cultural and Environmental Values and Tourism Product Diversification Under Cittaslow Requirements for Excellence

\begin{tabular}{ll}
\hline \multicolumn{1}{c}{ YALVAÇ } \\
\hline CITTASLOW REQUIREMENTS FOR EXCELLENCE & $\begin{array}{l}\text { PROJECT OUTPUTS OF YALVAÇ PROTECTION AND DEVELOPMENT OF CULTURAL } \\
\text { AND ENVIRONMENTAL VALUES AND TOURISM PRODUCT DIVERSIFICATION }\end{array}$ \\
\hline
\end{tabular}

Energy and environmental policies

Infrastructure policies

Quality of urban life policies

Agricultural, touristic and artisan policies

Policies for hospitality, awareness and training

Social cohesion

Partnerships
- building wastewater treatment plant

- decreasing noise pollution

- improving transportation system

- regulating traffic and shop signs

- rearranging town entrances

- sustaining archeological surveys in Antioch

- identifying and registering historical buildings and sites

- rehabilitating of monuments, vernacular architecture and urban areas

- rearranging new and existing squares

- constructing sports fields

- setting up a town museum, library and neighborhood art galleries

- reorganizing industrial areas

- generating cultural routes

- identifying and maintaining intangible cultural heritage

- reorganizing recreation and forest areas

- planting, seedling and designing green areas

- rehabilitating traditional craft bazaars and establishing new craft centers

- generating market places for women employment

- organizing producer and peasant markets

- promoting eco-agriculture, eco-farming and eco-tourism

- preserving and featuring local food products and promoting their marketing

- rearranging farming areas for buffalo breeding

- rearranging local fruit and vegatable gardens

- rehabilitating old wooden houses in Hisarardı Village for eco-tourism purpose

- restoring historical buildings to reutilize them as guest houses

- introducing, revitalizing and maintaining traditional crafts such as felt, blacksmith, saddler, leather, etc.)

- training apprentices in traditional crafts, recording and keeping traditional crafts production processes digitally

- establishing restaurants cooking with local products and traditional recipes

- arranging a history-themed park

- publicizing town's tourism in national and local extent

- restoring old leather factory reutilizing it as a hotel

- preparing bilingual brochures about town

- placing orientation signs into historical zones

- raising awareness of pupils by giving courses about town's history and heritage

- supplying employment for women

- being in collaboration with Turkish Union of Historical Towns, The Foundation for The Promotion and Protection of The Environment and Cultural Heritage, universities, non-governmental organizations and Ministry of Culture dents from Yıldız Technical University, Çukurova University and Süleyman Demirel University in 2002. Since then, Yalvaç Municipality has been rehabilitating the traditional houses and neighborhoods with the support of local community and specialists from the Foundation for the Protection and Promotion of the Environment and Cultural Heritage. West
Mediterranean Development Agency also subsidized for the expenses of the restoration projects of some historical houses under the name of "Financial Support Program of the Development of Alternative Tourism" in 2013. ${ }^{36}$

\footnotetext{
${ }^{36}$ Yalvaç Belediyesi, 2009.
} 

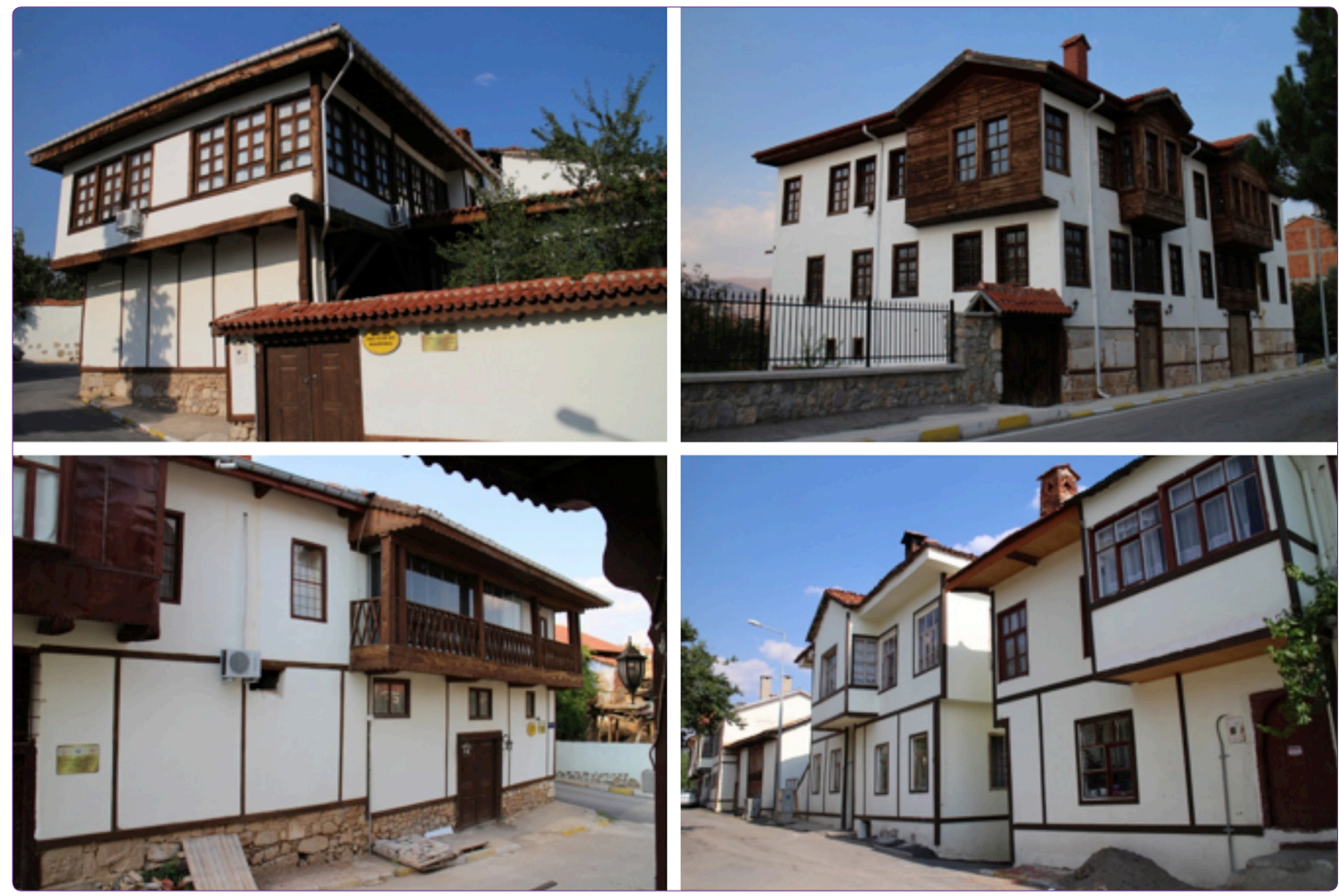

Figure 7. Examples from Rehabilitation of Vernacular Architecture.

The purpose of this project, carried out in two stages in 2002 and 2009 consecutively, is to identify natural, cultural and archeological assets, traditional lifestyles and cultures and to provide tourism oriented economic and social development through developing and maintaining them as a whole. ${ }^{37}$ Within this framework, some of the following project outputs are realized and some of them are foreseen to be realized in progress of time: ${ }^{38}$

Rehabilitation of Historic Buildings and Urban Areas: Devlethan Mosque, which reflects the architectural features of the Beyliks Period, was restored by Regional Directorate for Foundations in 2005. Meanwhile, around the Mosque, the facades of buildings were enhanced, the signs of shops were reorganized and the layout of Mosque courtyard was rearranged by Yalvaç Municipality. Moreover, Bedesten, adjacent to the Mosque, was rehabilitated into a covered bazaar for the exhibition and sale of traditional crafts.

Traşzade Mansion was restored by Yalvaç Municipality with the help of the Foundation for the Protection and Promotion of the Environment and Cultural Heritage and converted into Yalvaç Cultural Center.

The restoration project of Old Leather Factory, from Early Republican Period, was completed. Due to this project, it will be a hotel and an open air museum. The earlier leather processing machines are going to be displayed in

\footnotetext{
${ }^{37}$ Yalvaç Belediyesi, 2009. ${ }^{38}$ Yalvaç Belediyesi, 2009; Yalvaç Belediyesi, 2011.
}

the open air exhibition space in front of the building.

In Kaş Neighborhood, one of the most protected historic neighborhoods of town, traditional houses were repaired and their facades were rehabilitated. One of two historic Yalvaç Houses, purchased by the municipality, has been converted into a restaurant that serves local food and the other one into a guest house. The survey, restitution and restoration projects of neighborhood's traditional Turkish bath were approved.

In Görgü Neighborhood, another historical neighborhood, the facades of traditional houses were mostly renovated. One of the houses was functioned as cultural house by municipality and another one as a restaurant-café by Yalvaç Governorate and the Vocational School. A street in this neighborhood is going to be purchased and reorganized as an art street with Mustafa Bilgin Art House by municipality. Moreover, Rüştü Emek House will be a research center for Pisidia archeological studies and one of Turkish houses will be transformed into a town museum.

In Kızılca Neighborhood, some of the traditional houses were simply repaired. One of traditional houses is going to be town's observation house. In this quarter, contemporary architectural practices are planned to be realized compatible with its traditional pattern.

In Eski, Abacılar, Müderris and Sofular Neighborhoods, traditional houses were identified and their simple repairs and facade rearrangements were done (Figure 7). 
Archeological Surveys: Excavations began in Ancient Antioch of Pisidia in 2008. Survey has undertaken by Department of Archeology of Süleyman Demirel University. In this area, the floor mosaics of St. Paul's Church were repaired and a part of the repair work of western portal was carried out. Excavation and restoration works will be started in the vicinity of Men Temple so that temporary observation and service areas will be arranged. Also, around Hoyran Lake, archaeological surveys will be conducted.

Rearrangements of Squares: The floor coverings of Çınaralt Square -where 800 years old plane tree is standing-, facades of coffeehouses and shops facing the square and its urban furniture were renovated (Figure 8). Moreover, It was decided that the area in front of the municipality would be designed as a square which would introduce the town and give information to the visitors. This square, called "Narrating Square", was selected by a board of academicians, Chamber of Architects of Antalya and the Foundation for the Protection and Promotion of the Environment and Cultural Heritage among projects participated in a National Design Competition. Today, this square has been newly built according to the selected project (Figure 9). It is the starting point of Yalvaç cultural route which has been formed in time. Besides, smaller squares in tradition-

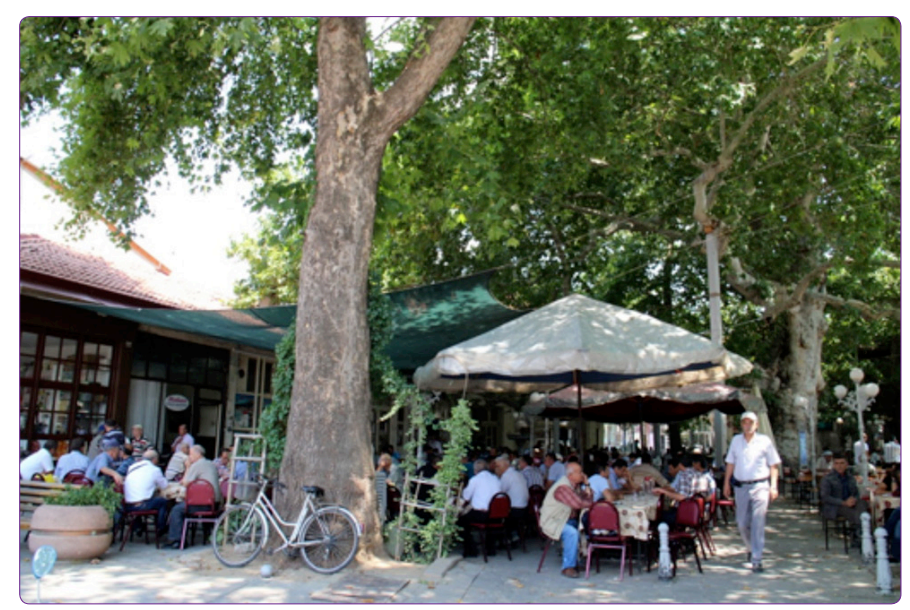

Figure 8. Çınaraltı Square.

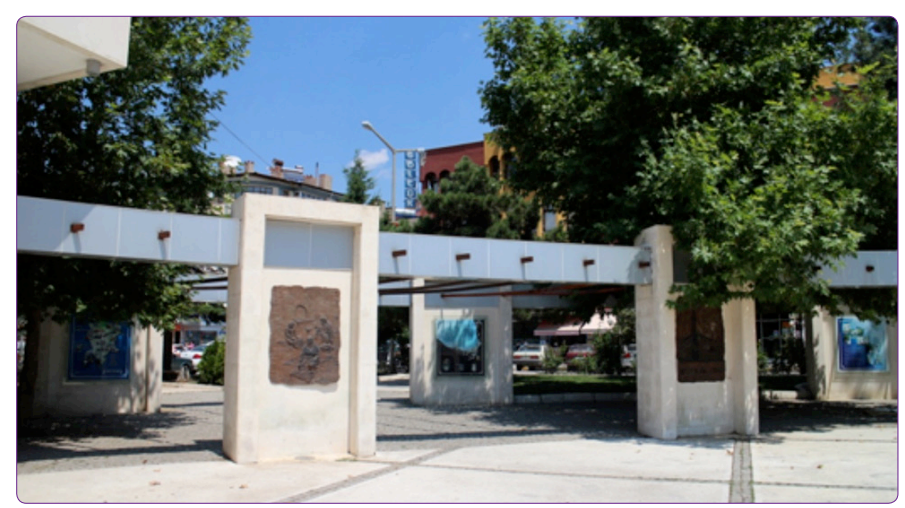

Figure 9. Narrating (Anlatan) Square. al neighborhoods are going to be rearranged by taking into consideration of their historical features.

Revitalization of Traditional Handicrafts and Cultural Values: In this context, Hidırlık Area will be transformed into a center for traditional handicrafts and culture. For the resumption of traditional furnace culture, the historic furnaces in traditional neighborhoods were repaired and rehabilitated. Furthermore, the area, where woodland and aqueducts meet, will be history-themed park about revival of how Yalvaç became a Turkish settled hometown. Some of the streets in the old town will be rearranged as an art street for various traditional and local handicrafts. Training of masters, assistant masters and apprentices will be encouraged on these art streets. Work has also begun on recording and maintaining the intangible cultural heritage.

Development of Rural Areas: Eco-farming, eco-agriculture and eco-tourism in Salur Neighborhood and Hisarardı Village will be encouraged. In Salur Neighborhood, fields for dairy products, cattle and poultry products will be established for eco-farming. In Hisarardı Village, vegetable and fruit gardens will be organized for eco-agriculture, old buildings will be rehabilitated for eco-tourism and education and sale areas will be rearranged for traditional handicrafts.

Reorganization of recreation and forest areas: In this context, picnic areas were arranged along the canal and Hisarardı Village. In addition, endemic plant species will be identified in the forest and woodlands and, walking trails and service areas will be formed in these areas. Around Hoyran Lake, landscape map will be designed and camping sites, water sports and beach facilities will be improved. The surrounding caves will be sanitized and opened to visit.

Construction of Sports Fields: Newly constructed Pelitalt Sports Field provides facilities such as football field, tennis and volleyball courts to urban residents. Besides, in Salur Neighbourhood, fields for wrestling will be created.

Establishment of Library: Within the scope of constituting children's library and education areas, Yalvaç Ural Children's Library will be established and education area will be arranged in front of this library.

Construction of Sewage Plant: At this sewage plant, established in 2007, only biological treatment can be done.

Rearrangement of Town Entrances: Town entrances have been defined by crossroad and median arrangements, installing urban furniture, art works, etc.

Reorganization of Industrial Areas: Protection bands for Organized Industry and Small Leather Industry will be provided and the location of leather district will be changed.

\section{Conclusion}

The new world order, which has emerged depending on globalization process, has caused many cultural and uni- 
versal values to be changed and eroded. Therefore, daily life in today's world has been digressing from its original meaning by accelerating with an increasing pace.

The sensitivity and attention that is shown in the use of authentic products made with difficulties by human power and skills, has transformed into the manner of buy-consume-throw away depending on mass production methods. However, the actual situation which can be acceptable to a certain extent for consumer goods in consequence of growing population, has been diminishing unwittingly our desire and habits of appreciation and conservation practices in every fields first ideational and later actional.

These attitudes may cause irreversible destruction of natural, cultural and historical values, especially for small urban settlements. Therefore, particularly in small historic settlements, it should be a duty and responsibility for everyone both to consider slow approach and urban conservation practices together and to create awareness and consciousness in order to transmit existing values to the next generation.

On the other hand, Yalvaç presents a multi-dimensional (physical, social, cultural, economic, ecological) urban conservation model with aforementioned "Project of Yalvaç Protection and Development of Cultural and Environmental Values and Tourism Product Diversification" initiated in 2002. The unrealized project items and the deficiency in the implementations are some of the main problems of urban conservation field in Turkey and a different research topic which needs be discussed. However, the presence and treatment of such a project prepared with an integrated conservation approach, has taken the initiative to create favorable conditions for a better town management. Because, particularly in historical urban settlements, each right step for protecting the cultural values of the settlements not only protects and maintains the historic buildings and sites but also contributes to urban management model aimed at increasing the quality of urban life. In this sense, Cittaslow Association, which targets to make small cities/towns more livable by city management, approved the membership of Yalvaç easily by overlapping the project developed for conservation intention with its own requirements.

Based on this case study, it is understood that Cittaslow Movement and urban conservation approaches contain similar and overlapping notions in their essence within the context of Slow. From this point of view, it is foreseen that both disciplines may support and develop each other mutually.

\section{References}

- Akkan, Ş. (2006) "Isparta Yalvaç Kaş Mahallesi Geleneksel Konut Dokusu Koruma ve Geliştirme Önerisi", Yüksek Lisans Tezi, Gazi Üniversitesi, Mimarlık Fakültesi.

- Hatipoğlu, B. (2015) “Cittaslow: Quality of Life and Visitor Experiences", Tourism Planning and Development, 12(1), s.2036.

- Honore, C. (2008) Yavaş, Alfa Yayınları.

- Isparta Valiliği II Kültür ve Turizm Müdürlüğü (2010) Isparta Kültür Envanteri, Cilt 2.

- Miele, M. (2008) "Cittaslow: Producing Slowness against the Fast Life, Space and Polity", 12(1), s.135-156.

- Özmen, A. (2016) Tarihi Cittaslow Yerleşimlerinde Kentsel ve Mimari Koruma İlkeleri, Doktora Tezi, Yıldız Teknik Üniversitesi, Mimarlık Fakültesi.

- Parkins, W. ve Craig, G. (2006) Slow Living, Bloomsbury Academic.

- Pink, S. (2007) "Sensing Cittaslow: Slow Living and the Constitution of the Sensory City", The Senses and Society, 2 (1), s.59-77.

- Pink, S. (2008) "Sense and Sustainability: The Case of the Slow City Movement", Local Environment, 13(2), s.95-106.

- Radstrom, S. (2011) "A Place Sustaining Framework for Local Urban Identity: an Introduction and History of Cittaslow", Italian Journal of Planning Practice, I(1), s.90-113.

- Uluslararası Cittaslow Birliği, Uluslararası Cittaslow Tüzüğü, 2014.

- Yalvaç Belediyesi (2009) Yalvaç Kültürel - Doğal Değerlerin Korunması, Geliştirilmesi ve Turizmin Çeşitlendirilmesi Projesi, Yalvaç.

- Yalvaç Belediyesi (2011) Yavaş Şehir Mükemmeliyet Koşulları, Değerlendirme Formu, Yalvaç.

\section{Internet Sources}

- Cittaslow International Web Sayfası, Philosophy. Available from: http:// http://www.cittaslow.org/content/philosophy [Accessed 15 November 2015].

- EXPO 2015 Milan - Italy is exporting the Cittaslow idea all over the world (Second Global Report on the Cittaslow Towns). Available from: www.cittaslow.org/article/expo-2015-milanitaly-is-exporting-the-cittaslow-idea-all-over-the-world [accessed 19 June 2015].

- Isparta II Kültür ve Turizm Müdürlüğü Web Sayfası, Aziz Paulus. Available from: http://www.ispartakulturturizm.gov.tr/ TR,71232/st-paul-aziz-paulus.html [accessed 28 August 28].

- Yalvaç Kaymakamlı̆̆ı Web Sayfası, Yönetim. Available from: http://www.yalvac.gov.tr/yonetim [Accessed 29 August 2016].

- Bu makale, 2016 yılında Yıldız Teknik Üniversitesi Fen Bilimleri Enstitüsü Mimarlık Anabilim Dalı Restorasyon Programı'nda Prof. Dr. M. Cengiz CAN'ın danışmanlığında Ayça ÖZMEN tarafindan yapılan "Tarihi Cittaslow Yerleşimlerinde Kentsel ve Mimari Koruma ilkeleri" başlıklı Doktora Tezi'nden üretilmiştir. 